\title{
THE STRATEGIC ROLE OF UNUSED SERVICE CAPACITY
}

\author{
Ng, Irene C. L., Wirtz, Jochen, and Lee, Khai Sheang
}

\author{
Published in: \\ International Journal of Service Industry Management, \\ Vol. 10, No. 2, pp211-238, 1999
}

Irene $\mathrm{Ng}$ is the Chairman of C L Ng \& Associates (H.K.) Ltd, a marketing consulting firm operating out of Malaysia, Singapore and Hongkong, and also the Group Vice Chairman of Sri America Group companies, a group comprising of various service firms in Malaysia. She is currently pursuing her doctoral degree in the National University of Singapore, Department of Marketing. Jochen Wirtz and Khai S. Lee are with the Department of Marketing, National University of Singapore.

The authors thank James Fitzsimmons for his insightful comments on earlier versions of this paper, as well as participants of the $5^{\text {th }}$ International Research Seminar on Service Management, organized by IAE, Aix-en-Provence, France, for constructive feedback on a presentation of an earlier version of this paper.

Please address all correspondence to the first author at the following address: 12, Jalan Bukit Bintang, Wisma SA, Kuala Lumpur 55100, Malaysia, Tel: +60-3-2429321, Fax: +60-32489226, E-mail: ireneng@pc.jaring.my.

1

Ng, Irene C. L., Wirtz, Jochen, and Lee, Khai Sheang, (1999) “The Strategic Role Of Unused Service Capacity,” International Journal of Service Industry Management, Vol. 10, No. 2, pp211-238 


\title{
THE STRATEGIC ROLE OF UNUSED SERVICE CAPACITY
}

\begin{abstract}
Services are by nature perishable. As such, managing a service firm's capacity to match supply and demand has been touted as one of the key problems of services marketing and management practice. This paper advances an alternative perspective of unused service capacity. Based on a review of current literature and an exploratory study, this paper employs a theory-inuse methodology to map out a set of capacity strategy propositions. These propositions show that unused capacity could be employed as a resource to achieve a series of strategic objectives that serve to improve the performance of the firm. The paper also suggests a re-look at capacity policies and proposes that service firms should therefore approach capacity management not only from the standpoint of operations management but from that of marketing as well.
\end{abstract}

Keywords: Capacity Management, Service Strategy, Theory-in-use. 


\section{INTRODUCTION}

Services account for a growing percentage of the gross national output of most countries. As such, service industries are maturing and have become more competitive, and there is a growing need to increase efficiency, productivity and competitiveness (Wirtz, Lee and Mattila 1998). To that end, the capacity of service firms has to be managed to achieve maximum and/or optimum utilization at all times, if possible.

Despite its importance, there has been a lack of attention devoted to the study of service capacity in the academic literature. Our field interviews indicated that managers in service firms face a complex and difficult task with regard to capacity management, and have less than adequate information to assist them. Furthermore, we noted that there seems to be a divergence between what companies should do, according to academic literature, and what they are actually doing. This divergence seems to occur, because the literature often ignores the role of strategy when dealing with capacity issues. As competition intensifies, and despite a dearth in literature, many service firms have learned to survive by creating and innovating strategies with regard to capacity, which have not yet been explored in the academic literature. It is the purpose of this paper to map such practices, conducted in complex real world settings, and formalize the theory within which they operate through a theory-in-use methodology.

As this paper deals with the role of unused capacity as a strategic resource for service firms, insufficient capacity to cope with overfull demand is not addressed here. We begin with a literature review on capacity management that will serve to illustrate the inadequacies of academic literature in providing solutions. Following on, the method section outlines the details of the exploratory investigation of thirty-six service firms and their practices of capacity usage. These interviews with the top management of the firms, mapping of their practices, coding and categorizing through a theory-in-use methodology, generated qualitative data and, supplemented by academic literature, formed the basis for seven sets of propositions. We then close with a discussion on the implications of the findings, study limitations and directions for future research.

\section{CAPACITY MANAGEMENT - A LITERATURE REVIEW}

Capacity of a service firm is "the highest quantity of output possible in a given time period with a predefined level of staffing, facilities and equipment" (Lovelock, 1992, p. 26). Capacity amongst service firms has one commonality. For each day a service is not put to profitable use, it cannot be saved (Bateson, 1977; Thomas, 1978). This perishability suggests a need for careful planning and management, as idle capacity due to slack demand, as well as turning away customers due to insufficient capacity, are serious problems critical to the success of many service firms (Harris \& Peacock, 1995).

There is substantial literature on how to cope with supply and demand imbalances (e.g., Heskett, 1986; Lee, 1989; Lovelock, 1988; Mabert, 1986; Maturi, 1989; Morrall, 1986; Orsini and Karagozoglu, 1988; Sasser, 1976; Shemwell \& Cronin ,1994). The literature suggests two ways of dealing with excess or idle capacity. The first is to manage supply to fit demand. Such strategies include reducing a firm's manpower costs, donating work to charity, conduct training for staff, schedule the service so as to match the peaks and the troughs, taking on sub-contracted

3

Ng, Irene C. L., Wirtz, Jochen, and Lee, Khai Sheang, (1999) “The Strategic Role Of Unused Service Capacity,” International

Journal of Service Industry Management, Vol. 10, No. 2, pp211-238 
jobs, and even reducing fixed costs such as renting office space or equipment. The second strategy, to manage demand to fit supply, include offering discounts, lowering prices, increasing advertising, conducting cold-calls, diversify to segments where demand is less fluctuating, selling services under barter arrangements, offering different services, positioning a service differently, accepting reservations, and even use idle staff as walking advertisements. However, if a firm chooses not to deal with the problem, it can take the option to stay with a fixed capacity that is capable of handling peak business.

In sum, the current literature mainly proposes reducing/scheduling capacity, and increasing selling and promotion activities ('chasing' demand) or stay with a 'level' capacity (Sasser, 1976).

Yet despite such techniques suggested by literature to alleviate the problem, capacity management remains complex and troubling in management practice and serves as one of the principal problems in services marketing (Zeithaml, Parasuraman and Berry, 1985).

Problems of Capacity Management. Typically, the objective for many service firms is to develop a capacity profile to such an extent that it matches its demand profile and yet retain its economic viability. In a perfect situation, a service firm is able to cut capacity during low season and increase capacity during peak season. However, despite an optimum choice of capacity to the extent that there may be a close fit to the demand profile, demand forecasting is a skill rather than an exact science (Dilworth, 1992). Disequilibrium from other extraneous factors may blunt such forecasts' predictive capabilities. Finding use for idle capacity in such situations would be a marketer's conundrum.

Also, not all service firms are able to fit capacity to its demand profile. This is because services can rarely achieve consistent utilization of their capacity - unless they operate through appointments (Dilworth, 1992). Even then, idle capacity may still be maintained in anticipation of potential business. When demand fluctuations are intermittent and too short in duration and there exist constraints to scaling capacity up and down, many of the proposed techniques may not be workable. This is often true with many service companies within the leisure industry, for example, hotels and car rental companies. Many of these service firms experience high fixed capacity and high perishability, and their profitability is largely tied to utilization (Allen, 1988). The result is usually a greater emphasis on short term gains and a myopic sales team, which strives to maximize yield during peak season and engaging in fierce price discounting to fill capacity during the low periods (Stone, 1990).

Moreover for certain services, idle capacity is required to make room for the variability of services to target to different market segments. Indeed, some estimates show that the quality of a services drops rapidly when demand exceeds even as low as $75 \%$ of the service firm's capacity (Heskett, 1986). This is because the comfort of other service users may be compromised, if the capacity of the service firm is used to the hilt.

Likewise, other services maintain some idle capacity as the availability of the services on-demand is necessary to establish and maintain service quality and the firm's differentiation efforts (Bassett, 1992). Examples of these services would include tow truck services, lift maintenance and other emergency services, or service companies that differentiate themselves through quality and short waiting times. For such services, unavailability or waiting for the service is invariably poor service, and many firms will set capacity utilization low enough to provide near instant service, or at least, where the level of service is competitive and satisfactory

Ng, Irene C. L., Wirtz, Jochen, and Lee, Khai Sheang, (1999) “The Strategic Role Of Unused Service Capacity,” International Journal of Service Industry Management, Vol. 10, No. 2, pp211-238 
against industry standards. In such cases, excess capacity is deliberately maintained to justify its employment during peak times (Bassett, 1992; Hope \& Muhlemann, 1997). The question then arises as to what can be done about the excess capacity during low periods.

Capacity Management is Complex. Clearly, capacity management in services is not a simple issue. Traditionally, its dynamics has been relegated to the domain of logistics and operations management, a legacy of its counterpart in goods manufacturing. It is apparent, however, that service capacity management is far more complex. This complexity is underlined in a service firm's inability to inventory its service as opposed to goods manufacturers that are able to do so when excess capacity arises.

Furthermore, many services require the customer to be present for a service to be performed (e.g., Berry, 1987; Lovelock, 1983). Consequently, capacity management for services would affect the customer more than in the case of a manufacturing plant scaling up and down its capacity, since issues such as quality, waiting times, unavailability (i.e. marketing issues) are linked intricately to capacity. Normative research in services marketing has recognized this decentralization of the service marketing function (Gronroos, 1980 \& 1991; Gummesson, 1979 \& 1991; Langeard et al., 1981), which involves issues relating to operations management and planning as well.

Understanding the complexities of services capacity management is only a start. To actually propose means of handling unused capacity is a different issue altogether, which, as demonstrated above, exist in some form or another in almost all service firms. Compounding this is the fact that some service industries have relatively low entry barriers (Normann, 1984). As such, new entrants would often create an excess capacity situation in the industry, at least in the short term. In such instances, competition often intensifies, price wars are created and profitability is compromised (Porter, 1985). Although the strategies suggested in the current literature have some virtues, the defensive undertones of such strategies suggest an inclination toward mitigating losses, and do not adequately assist companies in tackling the problems of unused capacity. Indeed, our field interviews indicate that such techniques are not frequently used in many service firms.

The above highlights two major issues that are pressing concerns of service capacity management. First, unused capacity will exist, in some form or another. Second, techniques that are suggested by current literature are too limited to provide meaningful solutions.

The objectives of this study are to ascertain first, how service firms deal with unused capacity in such a way so as to reduce its occurrence and its magnitude, and second, to map the actions undertaken. Such actions would then be compared against the literature and formalized into a set of propositions.

\section{METHOD}

A few exploratory interviews conducted before the study was designed indicated that many service firms handle their unused capacity in very different ways. This divergence between practice and what the literature suggests is the backdrop against the reasons why a theory-in-use methodology seems warranted.

\footnotetext{
Ng, Irene C. L., Wirtz, Jochen, and Lee, Khai Sheang, (1999) “The Strategic Role Of Unused Service Capacity,” International
} Journal of Service Industry Management, Vol. 10, No. 2, pp211-238 
In their book 'Theory Construction in Marketing: Some Thoughts on Thinking', Zaltmann, LeMasters and Heffring (1982, p. 113) illustrate the fundamental concept of a theoryin-use approach:

"Practitioners........ are generally more concerned with informal theory based on everyday observations (versus controlled experiments), having less than precise concepts (versus explicit empirical referents), and being related to one another intuitively (versus in rigorous testable relationships). The informal theory built and maintained by practitioners in their everyday activities represent an important source of insight for the researcher concerned with formal theory. By mapping these informal theories and applying their own creativity, a researcher may gain insights into marketing phenomena which might not otherwise be obtained."

This methodology is therefore an exercise in reconstructed logic; mapping informal theory, linking with academic literature and developing a greater understanding of the phenomenon. The rationale for this approach, applied in this study, is embedded in the pursuit of knowledge ${ }^{1}$, in the truest sense of the word. The purpose is to understand, formalize and document practitioners' strategies in handling capacity as a contribution to academic literature.

A case study of a cruise line first provided the authors with insights on the various innovative usage of capacity. Although a single case study would still be relevant in this methodology (Zaltmann, LeMasters and Heffring, 1982), multiple subjects were subsequently chosen as a way of discovering patterns in their strategies, how they were commonly employed, and whether such strategies exist across a diverse range of service firms. It is to be noted that this approach involves considerable interaction with the individual subjects. Hence, in-depth interviews with the top management of thirty-six service firms in Malaysia and Singapore were performed. Table 1 shows the sample composition by industry.

$<$ Take in Table $1>$

The managers were carefully selected to ensure that they were from the firms' senior management and had access to relevant information with regards to the firms' capacity usage. Care was also taken to ensure that the manager chosen had access to meetings and decisions that would offer insights to the firms' reasons for such capacity usage. As such, the managers interviewed in the sample mostly consist of top managers, i.e. CEOs and decisions makers in the firms. These thirty-six firms fall within the four quadrants of the Service Process Matrix (See Schmenner, 1986) and would therefore constitute a comprehensive sampling of service firms.

For the purpose of this paper, we were interested in how service companies deal with their unused capacity, the actions taken by the company to alleviate the problem, and the companies' reasons for their actions. A review of existing literature was then performed. The combination of literature and the strategies employed by the firms were then developed into a set of propositions.

\footnotetext{
${ }^{1}$ Knowledge, as defined by a well-known sociologist of knowledge, Burkart Holzner, is the mapping of experience reality by some observer (Zaltmann, LeMasters and Heffring 1982). 6
}

Ng, Irene C. L., Wirtz, Jochen, and Lee, Khai Sheang, (1999) “The Strategic Role Of Unused Service Capacity,” International Journal of Service Industry Management, Vol. 10, No. 2, pp211-238 


\section{DEVELOPMENT OF PROPOSITIONS}

In this section, a set of propositions on capacity related strategies is derived from findings from the study and supplemented with literature. The underlying concept of these capacity strategies seems to be the firms' proactive intention of ensuring that a firm's capacity is efficiently and productively utilized. The identified strategies were categorized into seven groups. In particular, firms use service capacity for (1) customer development, (2) bundling, (3) pledging, (4) employee endowment, (5) exchanging, (6) entry deterrence, and (7) differentiation. Table 2 outlines each of the capacity strategies and the percentage of the thirty-six companies interviewed that practice these strategies.

\section{$<$ Take in Table $2>$}

\section{Capacity for Customer Development}

$89 \%$ of service firms in our study use at least some of their capacity to develop customer relationships, either by (a) building loyalty, and/or by (b) providing trials. Of the $89 \%$ companies that employ customer development strategies, $81 \%$ of the firms use some of their capacity to build loyalty, and $50 \%$ use capacity to allow customers to sample their services through free trials.

Customer Development by Building Loyalty. Many loyalty programs of service firms in our study utilize the firm's capacity as an instrumental tool. For example, airlines give free tickets in exchange for the accumulation of miles through their frequent flier programs, and hotels give free room nights to their regular patrons. In less formal ways, many professional firms provide free advice and research to their regular clients.

As we discovered in our study, the use of capacity in building loyalty is perceived to be advantageous for at least four reasons. First, in some services, giving away such "freebies" may create a "snowball" effect that increases sales, as a customer who is given a loyalty-driven voucher may purchase additional services from the firm. For example, the traveler may travel with a friend or spouse, who will have to purchase another ticket. Second, giving away a service as a reward as opposed to cash invokes "images" or "mental pictures" that trigger emotional responses. A previous redemption of a loyalty-driven dinner voucher, for example, could have provided an evening of such vast enjoyment that a customer would attach a higher value to similar future rewards than mere cash. Third, a customer may value a service according to its most visible price (for example, gross fare of an airline seat) and because the most visible price is usually a higher price, the customer feels that he has received a greater loyalty benefit (cf. Alonzo, 1996). Finally, the company attains cost efficiency from providing capacity as a reward as opposed to giving other loyalty rewards that may need to be purchased.

Customer development through trials. Some service firms in our sample use capacity to provide potential customers with 'trials' that allow customers to experience the service before making a purchase decision. For example, the health club in our study runs programs for members to bring along a friend to try out their facilities. Such trials are always conducted carefully and closely monitored by the firms to ensure that there is no abuse. Netscape new beta version browsers, for example, could be sampled for two weeks before the software automatically expire and all its functions disabled.

Ng, Irene C. L., Wirtz, Jochen, and Lee, Khai Sheang, (1999) “The Strategic Role Of Unused Service Capacity,” International Journal of Service Industry Management, Vol. 10, No. 2, pp211-238 
Trials are also useful for developing channel relationships. In our study, agents selling into a new tourism product, such as a theme park, or a new destination, are often invited for free 'familiarization trips'. These familiarization trips are not merely incentives. They serve to amplify the agent's ability to sell the service in their home markets. One of the cruise lines in our study hosted a familiarization cruise for wholesalers and agents in five countries to develop new markets.

Of course, not all services are capable of providing such trials. It would not be possible for hospitals, for example, to provide trials of their services.

Summary of capacity for customer development. The preceding discussion is summarized in the following three propositions:

P1a: Unused capacity can be utilized to develop customer loyalty.

P1b: Unused capacity can be employed to develop new customers.

P1c: Unused capacity can be employed to develop new channels of distribution.

\section{Capacity for Bundling}

In our study, $83 \%$ of the firms set aside capacity to practice bundling as a strategy. Although bundling is used as a strategy for most of the service firms, our study discovered that there are different purposes why companies bundle. Our investigation isolated five purposes of bundling, and the proportion of the service companies driven by each purpose is shown in Table 2. Many firms cite multiple purposes for bundling. Before discussing each of the observed bundling strategies for utilizing capacity, we provide a brief review on the literature for bundling.

Background on Bundling Literature. Bundling is the parceling of two or more products, and marketing them at a discounted price. Service companies have long practiced the concept of bundling. Airline seats are bundled with tours and hotel accommodation, audit firms bundle auditing with company secretarial services, and advertising agencies bundle their creative talents with media buying services. Pure bundling is the offer of two or more services at a package price but does not provide the option of purchasing the individual services separately, i.e. in their unbundled form. Conversely, pure component selling is the selling of individual services in their unbundled state.

Whilst bundling strategies can serve as a powerful tool to a firm's marketing efforts, there may be arguments against its use. Switching from pure components to bundling may result in a potential loss in revenue. Customers who wish to buy a service individually may not be so inclined to purchase the bundled services. Furthermore, customers who already have had intention of buying the bundled services as individual services will now enjoy a lower price, and the service firm would have lost the additional margin it would have earned otherwise (Guiltinan, 1997; Venkatesh \& Mahajan, 1993). However, employing mixed bundling can circumvent some of these limitations. Mixed bundling provides the customer with both options, i.e. allowing them to choose whether to purchase the services in a bundle or individually (Schmalensee, 1984). Prices of services (whether sold individually or as a bundle) can be simultaneously optimized through mixed bundling in such a way that the service firm's profit can be increased over and above the expected profit than if the services were sold on a pure component basis (Adams \& Yellen, 1976; Schmalensee, 1984; Venkatesh \& Mahajan, 1993; Yadav \& Monroe, 1993).

8

\footnotetext{
Ng, Irene C. L., Wirtz, Jochen, and Lee, Khai Sheang, (1999) “The Strategic Role Of Unused Service Capacity,” International
} Journal of Service Industry Management, Vol. 10, No. 2, pp211-238 
With mixed bundling providing greater revenue as compared to selling products in their pure form, a service firm can set aside some of its capacity for the purpose of bundling with other services. Our study showed that the motivation for service firms to bundle is largely due to the strategic benefits obtained from it. Such benefits include bundling for improving service performance (mentioned by $90 \%$ of all the firms that reported to bundle to utilize unused capacity; see Table 2); for increasing demand (60\%); for segmenting markets $(60 \%)$; for reducing a service firm's selling risk (47\%); for cost reduction (37\%); and for obscuring discounts $(33 \%)$.

Bundling to provide better service value. Using part of a firm's capacity for bundling, in some cases, offers better service value and thus creates differentiation. Our study showed that an overwhelming $90 \%$ of companies that bundle, cite providing customers with better service and greater value as a strategy for bundling.

For example, in providing customized software services, many companies bundle their customized software services with support services to ensure satisfaction from the software's proper usage.

For many professional service firms in our study, such as legal and engineering firms, bundling with other services is often performed, because their clients only wish to deal with one single company or person to get the job done. Hence, the professional firm, such as an engineering firm, would not only offer its' capacity to provide a direct service to a client but would bundle some of its' capacity with other service firms, such as soil investigation and surveying, to market itself as a 'total solution' provider. For marine and port services, bundling various services together provides for better coordination, especially over time, when increase in bundled sales fosters closer relationships between the service firms and their bundling partners. From the customers' perspective, the availability of bundled services can sizably reduce search costs, providing them with the convenience of a 'one-stop-shop'.

Bundling to increase demand. Aside from providing better service value to customers, setting aside capacity for bundling was also used by $60 \%$ of firms that bundle in our study to increase demand. Through bundling, two products become a new 'bundled' product. If the two products are independent in demand, some customers who would buy only one of the products, if they were priced separately, will now buy both in the form of the bundle. The reason for this is that the value some customers place on one product is so much greater than its price that the combined value of the two products exceeds the bundled price (Guiltinan, 1987).

During the financial turmoil in Asia, Malaysians were willing to pay and subscribe to a bundle of 20 Cable Channels provided by ASTRO, the Malaysian Cable TV Distributor, although the demand was predominantly driven by the need for financial news information from $\mathrm{CNN}$ and CNBC Asia. ASTRO sold the cable channels through pure bundling and channels were not available for subscription individually.

Additionally, 'trade-up bundling' was used by some firms in our study, whereby various bundles are created with a slightly higher bundled price. Each higher price bundle includes an additional service and some enticement to motivate customers to 'trade-up' to the next bundle. For example, one health club in our study offered a higher discount for the purchase of a bigger bundle, comprising of facial, massage and manicure, as compared to a lower discount for the purchase of a bundle comprising of facial and massage only. 
Likewise, a customer, who is interested in buying a service from a service firm, is given a discount to purchase not merely the service itself, but a bundle of other services within the firm. This serves to increase customers' switching costs and reduce their motivation to try a service elsewhere (Eppen, Ward and Martin, 1991). As one manager in our study describes it, bundling assist the firm to get a "foot in the door so that it's easier to get the other foot in". By being a client's tax adviser, for example, an accounting firm can bundle tax consultation with regular year-end auditing services.

Bundling to facilitate reduction in selling risk. It was found that setting aside capacity for bundling offered, in many cases, an opportunity to lower the firm's selling risk ( $47 \%$ of the firms that use a bundling strategy). As the threat of perishability in services is high, service firms endeavor to lower their selling risk. In our study, some service firms find that by marketing their service in a bundled form, the bundle provides the firm with a discrimination tool to lower prices and target a segmented market that is willing to buy the service in advance. Thus, bundling facilitates a firm's attempts to reduce selling risk without cannibalizing existing pricing structures (cf. Venkatesh \& Mahajan, 1993). This is the case for many airlines. Through bundling and targeting customers who are willing to purchase in advance, they are able to sell their seats in advance to tour operators.

Bundling to reduce marketing costs. A bundling strategy serves to reduce marketing costs and provide scope economies for $37 \%$ of firms that use bundling. As the cost structure of many service businesses is characterized by a high level of cost sharing (cf. Dearden, 1978), the marginal costs associated with marketing and selling additional services to customers are often lower in comparison to the service firm's total cost (Guiltinan, 1987). As such, some service firms set aside some of their capacity for bundling to obtain reduction in marketing costs. A hotel that sells its membership programs, which are bundled forms of hotel services such as health clubs, food and beverage and rooms, gain from lower marketing and selling costs per service when the customers buy into the program.

Bundling to obscure discounts. In our study, $33 \%$ of the service firms that bundle use it as a strategy to obscure discounts (cf. Guiltinan, 1987). Service firms that have low capacity utilization and are yet unwilling to engage in a price war to sell capacity may be willing to reduce their price when selling through bundles. This can be done to the extent that a customer/competitor, who tries to ascertain the precise discounts provided by the services in the bundle, end with inconclusive information. This strategy is commonly employed in multi-service companies, who are willing to impart their unused capacity to cross sell at hefty discounts to obtain a larger market share. For example, the cruise line, as a subsidiary of a major corporation, bundled cruises with a sister service firm (a hotel) with both providing discounted rates to develop an overseas market coming in on a fly-cruise-stay program. The total bundled price was only marginally higher than the list price of the flight portion, which gave the perception that the cruise and the hotel were free.

Interestingly, in Malaysia where the airline industry is regulated and fare controls exist to the extent that penalties are imposed on airlines and agents who undersell to the market, selling airline seats in a bundle can serve to obscure discounts given to the extent that an airline can sidestep such fare control regulations. In another example, the cruise line casino in our study provided free air tickets and cruise for passengers, who were prepared to exchange a predetermined sum of money for casino gaming chips. 
Summary of capacity for bundling. From our study, it can be seen that setting aside a firm's capacity for bundling is a common strategy amongst service firms. Our interviews indicated that while some service firms sold their services completely through bundling, the proportion of capacity that is sold in that manner for most of the service firms ranges from 5\% to $50 \%$. The preceding discussion is summarized in the following set of propositions:

P2a: Unused capacity can be used for bundling to provide better service value.

P2b: Unused capacity can be used for bundling to increase demand.

P2c: Unused capacity can be used for bundling to reduce a firm's selling risk.

$P 2 d$ : Unused capacity can be used for bundling to reduce marketing costs.

P2e: Unused capacity can be used for bundling to obscure discounts.

\section{Capacity for Employee Endowment}

In our study, some service firms use capacity to endow employees and build loyalty and commitment within the company. Setting aside capacity for endowing employees is a capacity strategy, which if structured appropriately, can serve to be a powerful tool to reduce staff turnover. In examining the use of capacity for endowing employees, our study found that $64 \%$ of service firms interviewed provide free or discounted services to their employee (Table 2).

Background literature on the service employee. The quality of a service is often highly dependent on the people that deliver it. Back in the 1970s and the early 1980s, little emphasis was placed on the service employees. The mindset of service management then was to design quick and impersonal services, maximizing usage of facilities and reducing any possible individualistic intervention that could disrupt the flow of the operation. As competition intensified in the late 1980s and 1990s, a new service model emerged - that of putting service employees first, investing in, and finding ways to motivate them (Schlesinger \& Heskett, 1991). These human resource strategies often increase personnel costs, although if implemented appropriately, can indeed provide high returns on investment. A firm's capacity can, through employee endowment practices, serve not only to lessen the cost burden, but also be utilized proactively to reduce staff turnover.

Endowing to reduce staff turnover. $64 \%$ of service firms in our study utilize capacity to endow employees. For the larger service firms in our sample, such as the airlines, cruise lines and hotels, formal policies on staff endowment exist, and some have developed their endowment programs to highly sophisticated levels.

The cruise line in our study sets aside approximately $10 \%$ of its cruises for its in-house endowment scheme, and has a discount program running within the organization. While the employee and his or her spouse can cruise for free, discount levels exist for immediate and extended family members. A lower level of discount is extended even to the employee's guests as long as the employee cruises together with them. The management feels that this practice has brought many of the employees together and creates a better working environment. "We are happy when our staff wants to cruise. They become more involved with the product, and they become more committed towards the preservation of service quality on board," said the line's Vice President for Operations. "And when you bring your family and friends along, and your colleagues get to meet them, it's more personal and we become like one happy family - which goes a long way to building loyalty and commitment."

Ng, Irene C. L., Wirtz, Jochen, and Lee, Khai Sheang, (1999) “The Strategic Role Of Unused Service Capacity,” International Journal of Service Industry Management, Vol. 10, No. 2, pp211-238 
Airline endowment programs are also common within the industry. Free tickets for staff and family are perceived to contribute strongly to employee retention. Similarly, our study discovered that endowment perks, whether formal or informal, were commonly practiced for other service firms as well, from the availability of low interest loans to bank staff, free meals for restaurant staff to free post-natal programs for health club employees who are pregnant. Such endowment schemes although generally applied to unused capacity during the low periods, serve to motivate employees and are used to reduce staff turnover.

Summary of capacity for endowment. It is important to note that the remaining $36 \%$ of the companies do not practice using capacity for endowment primarily because these companies were performing industrial or professional services, such as port, advertising, engineering and architectural services, whereby endowing their employees with these services are not relevant. This would suggest that almost all consumer service firms use capacity to practice some form of endowment - although many of the smaller service firms admitted that such practices were adhoc and there were no formal policies on the matter. With committed and motivated staff, staff turnover is effectively reduced. Lower staff turnover, in turn, reduces learning curve effects, which can contribute to better service performance. The preceding discussion is summarized in the following proposition:

P3: Unused capacity can be utilized to increase staff motivation and loyalty.

\section{Capacity for Exchanging}

Some service firms exchange a portion of their capacity. In our study, 53\% of service companies interviewed used their capacity to participate in some form of exchange (see Table 2). Of these, $79 \%$ exchange capacity to reduce cost, $53 \%$ to extend their existing product range, $42 \%$ to reduce selling risk, and $26 \%$ of the service firms exchange capacity to improve yield.

Exchanging capacity for cost reduction. A substantial part of the promotional strategies for Internet giants, such as Netscape, Yahoo! and Excite, centers around the bartering of capacity on their web sites. Out of a total expenditure of $\$ 5.7 \mathrm{~m}$ on web advertising by Netscape in 1996, it is estimated that $60 \%$ of it was on barter. Says Scott Epstein, the director of marketing communications with Excite, "No one is selling 100\% of inventory. There is excess space, so why not put it to use through some sort of barter deal?" (Advertising Age, March 24, 1997, p. 26).

In our study, it was interesting to note that bartering capacity has taken on new levels of sophistication. Airlines barter their capacity for advertisements in magazines, promotional campaigns with travel agents, and even for entertainment expenses. For example, it is accepted practice in Asia for airlines and agent executives to socialize and conduct businesses outside the office - often on the golf course. As golfing is expensive, with a round of golf often costing US\$100 per person, one airline barters tickets (a portion of its capacity on selected flights) for a pre-determined number of rounds of golf a month, which the company executives utilize to entertain agents and clients. The golf club, consequently, uses the tickets for members' inter-club competitive trips overseas or as prizes for in-house competitions - and is strictly prohibited from re-selling these tickets.

Exchanging capacity for extending product range. In our study, 53\% of the service firms that exchange capacity are motivated by product extensions. For example, in 1995 Virgin Atlantic Airways signed a code share agreement with Malaysia Airlines (MAS). Under this

12

Ng, Irene C. L., Wirtz, Jochen, and Lee, Khai Sheang, (1999) “The Strategic Role Of Unused Service Capacity,” International Journal of Service Industry Management, Vol. 10, No. 2, pp211-238 
agreement, MAS is able to increase its number of flights on a congested route from 8 to 14 fights per week. With the increased capacity, MAS expected revenues to increase by $30 \%$ to $40 \%$. In exchange for the right to operate the additional flights, MAS allocates a portion of its increased capacity to Virgin Airways. Although technically 11 flights are to be operated by MAS and 3 by Virgin, all 14 flights were actually operated by MAS with Virgin given an allocation of seats for each of the 14 flights. Flight numbers are shared and a Virgin Airways attendant is on board for each of the flights. By exchanging capacity for traffic rights, MAS increased its revenue and Virgin expanded its services with a new route and higher frequency at minimal costs (Aviation Week and Space Technology, 1995).

Similar agreements allow for other innovative capacity strategies. One example which surfaced during the course of our study revealed that by exchanging some of its capacity on a domestic route with another country's airline, the local airline is able to fly passengers from its capital into domestic points of the other country and vice versa. Thus, both airlines are able to extend their services to more destinations, even if they do not fly those routes themselves.

Even among ocean liners, alliances to exchange capacity have expanded rapidly over the past few years to the extent that these pacts have now covered many lanes in the global shipping network (Bradley, 1995).

Exchanging capacity for higher yield. In our study, 26\% of the firms that use capacity to exchange claim to do so to facilitate yield management ${ }^{2}$.

The concept of overbooking in this modern age of yield management is not uncommon amongst service firms, especially in the airline business. This concept entails a service firm taking in customers' bookings to a level that exceeds its capacity in anticipation of customers who fail to turn up at the last minute. In the past, such overbooking tendencies have been under great scrutiny and criticism by consumers and government to the extent that in 1978, the US Civil Aeronautics Board decreed a plan to reduce the number of passengers being 'bumped' (the act of denying a customer a seat, which he has had a reservation for). The number of 'bumps' since then have been greatly reduced due to airlines providing incentives to customers who volunteer to wait for a later flight (Simon, 1994). Hence, an airline could exchange future or alternative capacity (at a discount) to free up existing capacity for customers who are willing to pay more. This 'voluntary bumping' has served to increase efficiency in capacity utilization for the airline and greater value to passengers.

For hotels that overbook, housing some of the overbooked guests in other nearby hotels is a commonplace strategy, as we discovered in our study. Providing some of one hotel's capacity for the other hotel that has overbooked in exchange for a portion of the latter's capacity should the same problem arise with the former hotel assist both parties in improving their yields and gaining higher revenue.

Summary of exchanging capacity. Although the exchange of service capacity is not a new concept, it is surprising that little academic literature has focused on it. Notable contributions focus on bartering and acknowledge that bartering allows for much more creativity than cash deals and should be viewed as an opportunity (Vaccaro and Kassaye, 1997). In 1992, bartering for advertising amounted to $\$ 3$ billion in the United States (cf. Lundberg, 1992). It is to

\footnotetext{
${ }^{2}$ Yield Management is defined as "maximizing the profitability of a [service] through manipulation of its pricing and booking policies' (Badinelli \& Olsen 1990).
} 
be noted, however, that some service firms admitted to exchanging capacity as a last resort, when they were unable to receive payment for the services rendered. As this was not a deliberate strategy and so as not to confound the data, such responses were not taken in as part of the percentage of companies practicing capacity exchange strategies. The preceding discussion is summarized in the following set of propositions.:

P4a: Unused capacity can be utilized to reduce a firm's cost.

$P 4 b$ : Unused capacity can be utilized to extend a firm's product range.

P4c: Unused capacity can be utilized to improve a firm's yield.

\section{Capacity for Pledging}

An innovative capacity strategy of pledging was practiced by $39 \%$ of companies in our study (see Table 2). By pledging some of their capacity to channel intermediaries, service firms display their commitment to the relationship, and thereby reduce potential opportunism. Before discussing the observed pledging strategy, we provide a brief review on the literature of distribution channels for services.

Background on Service Distribution Channels and Transaction Cost Theory. Careful analyses of the interviews conducted in our study suggest that service distribution channels are often difficult to establish for various reasons. The nature of services - their intangibility, inseparability, perishability, and heterogeneity make it difficult to relate how the "distribution" of a service can be accomplished (Light, 1986).

Service intangibility creates problems for the marketer, as not only potential buyers are not able to see or touch the services before consumption, but channel intermediaries would also have the same problem. Thus, the role of channel intermediaries in services tend to be more complicated than their counterparts in goods distribution, as service intermediaries have to convey the idea and the quality of the service to the consumer. As Stone (1990, p. 88) puts it, "How can you rely on the agency to position your product properly, particularly when perceptions and promise are the essence of selling?" To reduce problems associated with intangibility, services channel intermediaries have to be well trained and equipped to sell the service and convey the quality of the service to its fullest degree. Hence, they would need to invest in some measure of human assets specificity, to borrow the term from transaction cost theory.

The inseparability of many services of production and consumption may imply that direct sale is the only option and channel intermediaries may not be required. However, many services distribute a tangible representation of the service with a promise that the service will become available for consumption at some future time or date, for example, through an airline ticket, a hotel voucher or a meal coupon.

The heterogeneity of services may result in dissatisfied customers, and thus strain the relationship between channel intermediaries and the service firm. Problems of service heterogeneity would thus rely on the strength of the relationship between channel members for their solution.

Perishability of services also creates potential problems. In the effort to maximize yield and reduce unused capacity, many service firms practice yield management and multiple pricing. Channel intermediaries may find that the service may not be available at certain times and prices for the same service can vary, resulting in confusion and higher transaction costs for channel

14

Ng, Irene C. L., Wirtz, Jochen, and Lee, Khai Sheang, (1999) “The Strategic Role Of Unused Service Capacity,” International Journal of Service Industry Management, Vol. 10, No. 2, pp211-238 
participants. Such problems could be solved, if channel intermediaries can be guaranteed of a service's availability at a pre-determined price, which may not be in the interest of the service supplier as he is eager to improve yields.

It is obvious that the unique characteristics of services serve to compound the difficulties in establishing a meaningful relationship between service firms and their intermediaries. As such, these relationships are often fraught with conflicts, which in turn, give rise to intermediary opportunism (Light, 1986; Stone, 1990). In our study, some intermediaries (travel agents, for example) attribute the lack of a credible commitment from the principal as a main cause for such conflicts. Without a credible commitment, many agents do not feel sufficiently assured to invest in assets required to build the channel relationship. On the other hand, tourism suppliers are apprehensive in giving commitment, as they believe the agent will act in an opportunistic way, once a market is established.

Pledging Capacity to reduce opportunism. Anderson and Weitz (1992, p. 20) define pledges as "actions undertaken by channel members that demonstrate good faith and bind the channel members to the relationship. Pledges are more than simple declarations of commitments or promises to act in good faith. They are specific actions binding a channel member to a relationship."

Consistent with literature, our studies discovered that the tourism industry has been using capacity as a form of a pledge. Tourism suppliers, such as airlines and hotels, often provide agents a portion of their capacity as a form of commitment. Such commitments, often called 'allotments', are given to specific channel intermediaries, who are able to display their commitment in return to the supplier, for example, by expending some advertising and promotion funds in the market to promote the supplier's service, or sending their staff for adequate training (human asset specificity). As an example, a hotel in Singapore may provide a wholesaler in Japan with guaranteed allotment of rooms per night. The wholesaler, in turn, mounts a promotional program in the Japanese market for the hotel. With a guaranteed allotment (usually by way of a binding contract), the wholesaler can be assured of the supplier's commitment to his market, and the service provider gains the assurance of the wholesaler's investment.

Often, tourism suppliers would introduce further safeguards, such as formalization procedures $^{3}$, which would dictate the date when the capacity pledged to the wholesaler is released back to the supplier within a 'cut-off period' (i.e. the number of days before a service is to be performed). With formalization, transacting parties are more assured of each other's behavior, and such predictability fosters the relationship. Research has shown that formalization procedures reduce opportunism and increase the effectiveness of the relationship (Dahlstrom, Dwyer and Chandrashekaran, 1995).

Our studies show that for some service firms, formalization procedures dictating the cut off date when the pledged capacity is released back to the supplier, can be as long as one to two months from the actual date of service performance. Such an imposition would allow suppliers to put other potential customers on waiting lists and confirm them with the capacity released by wholesalers, who were unable to fill their allotments by the cut off dates. Consequently, even

\footnotetext{
${ }^{3}$ Formalization is the extent to which explicit rules and procedures regulate the behavior of the firms involved in the relationship (Dwyer and Oh 1987).
}

$\mathrm{Ng}$, Irene C. L., Wirtz, Jochen, and Lee, Khai Sheang, (1999) “The Strategic Role Of Unused Service Capacity,” International Journal of Service Industry Management, Vol. 10, No. 2, pp211-238 
though some may argue that pledging capacity with a guarantee of sale may be too risky, waitlisting potential customers (a form of inventorying demand), who will purchase capacity released after cut off date, will substantially reduce that risk, while still giving the service firm the benefits of the pledge.

The Asian cruise line in our study extended this concept further with a rather innovative deal involving the use of capacity. In their effort to expand their network into Australia, a marketing plan was drawn up. The total cost was estimated to be US\$60,000. This cost was split sixty-forty between the cruise line and the Australian wholesaler. However, the wholesaler was obligated to fund $100 \%$ of the amount up front and redeemed the $60 \%$ progressively over the year as sales materialized. The cruise line provided a guaranteed allotment of cabins; some form of service specificity on board the vessel specifically for the Australian market and total exclusivity to the wholesaler. Procedures for reservations were formalized with a twenty-one day cut off period so that any capacity not sold by the date was returned and sold to wait-listed customers from other market segments. The implementation of the marketing plan in Australia was monitored closely by both parties. With this deal, the cruise line was able to reduce the cost of market development, whilst the wholesaler was assured of the line's commitment to invest in the relationship.

Summary of capacity for pledging. Developing and maintaining distribution channels for services is a daunting task. As service industries are so diverse, their distribution channels development can differ to a large degree, and there seem to be no traditional channels to model after. The channels of distribution for a bank (for example, withdrawing money from an ATM) would differ greatly from that of a health club or an airline, although within the hospitality industry, there may be greater similarities.

Pledging capacity as a strategy to build channel relationships is a useful tool for many tourism service suppliers, as the sales mix for these service firms are often so geographically diverse that their limited marketing budgets tend to be ineffective. By pledging capacity, new markets can also be developed at lower costs. The preceding discussion is summarized in the following proposition:

P5: Unused capacity can be utilized to develop new markets.

\section{Capacity for Entry Deterrence}

Capacity can be used as a tool for entry deterrence. As the danger of new entrants into an industry threatens the profits of the incumbent within (Yip, 1982), the deterrence of new entrants is of paramount importance, and in fact strategies for entry deterrence often rank equal in importance as all other strategic decisions (Smiley, 1988). Our study shows that $25 \%$ of service firms interviewed expand their capacity to deter new entrants.

Academic literature argues that one of the strategies available to incumbents is to build enough capacity to lower prices (Gruca and Sudharashan's, 1995). Hence, whether increasing the number of staff or building a new hotel wing, the incumbent should be able to increase capacity with lower marginal costs. With an irreversible capacity choice and hence creating exit barriers for itself, the incumbent signals its capability of constantly increasing outputs to lower prices to a level, whereby it may not be commercially viable for potential new entrants to enter the market (Wenders, 1971).

16

\footnotetext{
Ng, Irene C. L., Wirtz, Jochen, and Lee, Khai Sheang, (1999) “The Strategic Role Of Unused Service Capacity,” International
} Journal of Service Industry Management, Vol. 10, No. 2, pp211-238 
Gruca and Sudharashan also commented that using capacity to deter new entrants is most effective in industries characterized by high fixed costs, large economies of scale and high producer concentration - traits exhibited by many service industries, such as hotels and airlines (cf. Thomas, 1978).

In our study, one airline expanded the capacity on certain routes to ensure that other carriers do not enter the market. Although the yield on that route might have been high, the airline deliberately created excess capacity and lowered its fares to deter other airlines from flying. This strategy was also extended to maintaining idle capacity when demand was slack (for example, three weekly flights to a destination were maintained instead of reducing it to two). In this case, the reasoning was to deter entry as well as an added benefit of retaining the flight slots (i.e. the time slot for landing allocated by the authorities at the destination), since relinquishing a time slot may allow potential competitors to take it over.

Similarly, a Malaysian telecommunication company invested heavily into expanding their network into as many geographical areas as possible, although the markets in these geographical regions may not yet be well established. Using capacity, and pricing the service at lower rates, the firm aggressively deterred any potential new entrant from entering these markets.

Many other people-based service businesses, such as consulting and professional firms, do not enjoy the benefit of capital as an entry deterrent. Although barriers can still be erected by way of service differentiation or developing proprietary technology (see Thomas, 1978), capacity is an alternative. An engineering firm that specializes in governmental infrastructure development claims to have a sizable share of the market. To maintain that share, the firm is careful to hire more people and yet quote at competitive prices to ensure that there is no incentive for new firms to enter and compete in that particular segment.

Interestingly, we also found that the motive to expand capacity is not merely to deter new entrants into the industry but to deter existing firms from entering a particular segment of the market.

The preceding discussion is summarized in the following set of propositions:

P6a: Unused capacity can be utilized to deter entry into a market segment.

P6b: Unused capacity can be utilized to deter entry into an industry.

\section{Capacity for Differentiation}

Capacity is also used as a tool to deliberately differentiate on quality. By keeping some capacity idle, customers enjoy greater comfort when consuming a service. Additionally, setting aside capacity often provides improved customer satisfaction through lower waiting times. Out of the thirty-six firms interviewed, 13\% reported to deliberately keeping idle capacity for these purposes.

The rationale for keeping idle capacity for differentiation is rooted the inseparability of services, i.e. the simultaneous production and consumption of a service. For many service firms, this inseparability implies that other customers can directly affect a customer's evaluation of a service (Bitner, Booms and Tetreault, 1990). For example, customers at a restaurant may not enjoy the service (even if the food is good), if the table next to them is making too much noise, or if their neighbors get involve in a drunken brawl. Likewise, a hotel guest may not be able to sleep well, if the nocturnal activities of the guest in the next room keep him awake all night. Whilst capacity may not eliminate such problems from occurring, it can reduce the impact of the

17

Ng, Irene C. L., Wirtz, Jochen, and Lee, Khai Sheang, (1999) “The Strategic Role Of Unused Service Capacity,” International Journal of Service Industry Management, Vol. 10, No. 2, pp211-238 
problem. For example, the restaurant patron can be moved to another table and the hotel guest shifted to another room - subject to available capacity.

In our study, a corporate weekly newspaper deliberately set editorial/advertisement ratio below industry norm, despite a potential loss in advertising revenue, for the purpose of maintaining less advertising clutter and thereby projecting a higher quality. The private hospital, maintains idle capacity for emergency purposes, whereas the health club keeps some $20 \%$ of capacity idle for the purpose of their members' comfort (a crowded aerobics session is a bane to members).

Furthermore, research shows that waiting for service negatively affects customers' evaluation of a service (Taylor, 1994). This was evident in our interview with a golf club, where despite potential loss in revenue, golf tee off times were kept ten minutes apart (against the industry standard of eight minutes), so that golfers did not need to wait too long between shots.

The preceding discussion is summarized in the following proposition:

P7: Unused capacity can be utilized to enhance service quality.

\section{DISCUSSION AND FUTURE RESEARCH}

In the preceding sections, we have examined how service firms use capacity as a resource and outlined the various capacity utilization strategies. A summary form of the capacity strategies is provided in Figure 1.

\section{$<$ Take in Figure $1>$}

Our findings indicated that whilst the capacity strategies of Customer Development and Employee Endowment, Entry Deterrence and Differentiation often use unused capacity, the capacity strategies of Bundling, Exchanging and Pledging are not directly applied on unused capacity. The firms, in fact, set aside a certain portion of their capacity in advance to employ these strategies. This is, in part, due to the benefits that can be obtained from the strategies but also due to a difference in time. As the firms may not be able to predict how much of their capacity will be unused at a certain future time, they preempt such possibility by committing a portion their capacity in advance through the employment of these strategies. This need for insurance due to the perishable nature of services, drive the capacity strategies just as it drives the concepts of reservations and overbooking.

It is interesting to note that what originally started, as a study on service firms and how they handled their unused capacity, seems to have obtained quite unexpected results. Along the course of our study, we discovered that many firms take a different approach towards capacity management, versus what some of the literature have suggested, namely, increasing selling activities and reducing capacity costs.

Specifically from the point of view of managing demand to match supply, many companies do not wish to pursue active discounting or increasing advertising and promotion activities to promote capacity utilization. Such moves are feared to impact negatively on marketing plans that have already been set in place. However, some service firms that are able to

\footnotetext{
Ng, Irene C. L., Wirtz, Jochen, and Lee, Khai Sheang, (1999) “The Strategic Role Of Unused Service Capacity,” International
} Journal of Service Industry Management, Vol. 10, No. 2, pp211-238 
accept advance sales, such as airlines and hotels, do practice reservations to diminish the impact of unused capacity, often in tandem with the capacity strategies.

From the point of view of managing supply to fit demand, our findings indicate that the scheduling of services was not a way to curb unused capacity but merely to mitigate losses. Even then, many firms admitted that the amounts saved are small as compared to the actual loss of income derived from the capacity that is unused. Hence, it would seem that firms are generally more keen in setting a 'level capacity' whilst employing the capacity strategies to strategically consume the unused capacity.

It can therefore be seen that the focus of these firms where capacity is concerned, is to act proactively to preempt and reduce the occurrence and magnitude of unused capacity. Hence our study suggests a divergence between academic literature and practice in so far as the focus and approach towards capacity management is concerned. In light of this, there is a need to shift current academic emphasis on capacity management and address the issue in a more proactive manner (cf. Bassett, 1992).

The striking factor in our study is that these proactive strategies utilize capacity itself as a strategic resource to improve business performance. This seems particularly advantageous for small and medium service enterprises, where resource constraints are a major obstacle in developing their businesses (cf. Donald et al., 1991; Lee, Wee and Chia, 1997).

A Possible Domain for Capacity Strategies. From the findings and the propositions developed in this paper, we were curious about the underlying reasons behind the use of these capacity strategies. What are the reasons behind the changing of a firm's perspective about capacity to the extent that solutions from literature is less practiced and capacity strategies thrive in its stead? Do these benefits provide a better outcome as opposed to suggestions from literature?

While our paper does not address the above questions, we would like, however, to advance a few arguments as a possible justification for the domain under which these strategies would prevail and the contextual nature of their existence.

Since capacity strategies are not known to be commonly practiced by goods marketing firms (with entry deterrence being an exception), the answer to the first question may possibly rest in the unique characteristics of services.

First, the perishable nature of services has various implications on capacity. For a service firm that has a capacity to perform a certain level of output on a particular date, unused capacity cannot be stored for use on a later date. In other words, services have no salvage value. This perishable nature of services drives service firms toward a greater urgency to maximize sales forward. It is our belief that this sense of urgency is therefore a driving force to some of the proposed capacity strategies.

Second, the intangible and inseparable natures of service are also likely to impact on capacity strategies. Intangibility and inseparability could possibly drive service firms toward a greater need to reduce perceive risk of purchase both by customers and by channel intermediaries. This need may also be another driving force for some of the proposed capacity strategies.

If service firms are driven by the above two needs, we can then further argue that these needs to change a service firm's perspective of capacity. In other words, the objective for a service firm is no longer to match demand and supply, but to maximize forward sales and reduce

19

Ng, Irene C. L., Wirtz, Jochen, and Lee, Khai Sheang, (1999) “The Strategic Role Of Unused Service Capacity,” International Journal of Service Industry Management, Vol. 10, No. 2, pp211-238 
perceived risk. To that end, the strategies employed are aimed to achieve these objectives, instead of merely matching supply and demand. With this shift in focus, we can understand why service firms would be more inclined to employ capacity strategies instead of the techniques generally suggested in the academic literature.

To summarize, we propose that, except for the use of capacity for entry deterrence which is practiced also by goods firms, the three unique characteristics of services (i.e. perishability, inseparability and intangibility) push the firm towards the strategic objectives of maximizing forward sales and reducing risk of purchase. With these strategic objectives, service firms would then employ the capacity strategies which would then lead to the strategic benefits of increase sales and improved profitability and which, in turn, lead to the outcome of improved business performance. A skeletal model amalgamating the above arguments is illustrated in Figure 2. It is hoped that our study would stimulate research to develop this model further.

$<$ Take in Figure $2>$

Other Research Issues. Our findings also suggested that operation policies and yield management practices often hinder the employment of capacity strategies. Many of the operations departments within the service firms interviewed treat capacity strategies as a necessary burden and a bane for depriving the company of more sales, as they tend to inhibit yield management practices. As such, marketing and sales teams constantly cross swords with operations and yield management teams in so far as capacity utilization is concerned, especially during peak seasons. The marketing and sales departments consider the practicing capacity strategies necessary, even during peak seasons, to ensure long-term revenue and to a large extent, assist in filling up capacity during the low seasons. The operations departments, however, are concerned with short-term yields and would constantly attempt to fill up capacity at high rates with little concern for the marketing implications. In our interviews, we discovered that this conflict between short-term yield and long term revenue seems to be a constant battle within many service firms.

Such a conflict provides an avenue to investigate further the cost of unused capacity. Being able to cost unused capacity, whether in terms of actual cost or opportunities lost, can be a starting point towards evaluating potential pay-offs obtained from employing the various capacity strategies proposed. However, research acknowledges that the guidelines and policies towards accounting and measuring unused capacity are still vague (Brausch \& Taylor, 1997; McNair, 1994). Without the ability to cost unused capacity, and thereby assessing capacity strategy pay offs, conflicts between short-term perspectives and long run increases in revenue will continually persist. It is hoped that future research shall also delve deeper into this area.

Besides the managerial implications from our presentation of capacity strategies, the theoretical aspects suggest a host of future research possibilities. Within each capacity strategy, more empirical research is required, which we believe will serve to develop our understanding of its usage further.

Finally, this paper does not address the issue of under capacity, i.e. when demand outstrips capacity. The predominant emphasis of this paper is the use of unused capacity as a strategic resource. As such, should the happy problem of excessive demand and insufficient

Ng, Irene C. L., Wirtz, Jochen, and Lee, Khai Sheang, (1999) “The Strategic Role Of Unused Service Capacity,” International Journal of Service Industry Management, Vol. 10, No. 2, pp211-238 
capacity be encountered, there is no unused capacity to speak of, and thus, no such resource is available.

A major contribution of this paper is the advancement of an alternative and pro-active view of a service firm's capacity as a strategic resource, through a theory-in-use methodology, manifested onto seven propositions. It is our belief that this contribution provides pedagogical benefits and substantial relevance to the practice of services management and marketing thinking.

\section{CONCLUDING REMARKS}

A service product is unique because of its intangibility, perishability, inseparability of production and consumption, and heterogeneity (cf. Berry \& Parasuraman, 1991). These unique characteristics pose special challenges to service marketers, and therefore require them to be more creative in developing marketing strategies (Reddy, Buskirk and Kaicker, 1993). With strategic planning and the development of competitive strategies playing a more important role in service companies (Wilson, 1988), a company's resources have to be managed so as to maximize its revenue according to the fluctuations in demand.

Service firms should view their capacity as an opportunity to formulate strategic plans and to exploit this opportunity to achieve maximum gains. As this paper has illustrated, capacity of a service firm can be utilized to improve business performance.

As noted earlier, capacity management is often thought of as an operations management issue. Such delineation can be counter-productive, as the development of a firm's core competence is in its ability to work across functional organizational boundaries (Prahalad \& Hamel, 1990). By working across functional boundaries, service companies can then boost efficiency and productivity and remain competitive. As an added emphasis and to aptly depict the essence of this paper, we would conclude with the words of Ohmae (1982, p. 39):

"...Even when the company has in effect no more management resources than its competitors in the same business or trade, it can often achieve resounding competitive success, if it is effective in bringing these resources to bear on one crucial point."

We believe the crucial point for competitive success in services hinges on efficient capacity utilization, and that the use of capacity, as the service firm's invisible but powerful resource, will bear on that point. 
TABLE 1

COMPANIES INTERVIEWED BY INDUSTRY

\begin{tabular}{|c|c|c|}
\hline Industry & No. of Companies & Subtotal \\
\hline $\begin{array}{l}\text { Professional } \\
\text { - Consulting Firms } \\
\text { - IT Firms (Software Programming) } \\
\text { - Law Firms } \\
\text { - Marine Services } \\
\text { - Advertising Agency } \\
\text { - Architectural Firm } \\
\text { - Engineering Firm } \\
\end{array}$ & $\begin{array}{l}6 \\
2 \\
2 \\
2 \\
1 \\
1 \\
1\end{array}$ & 15 \\
\hline $\begin{array}{l}\text { Hospitality } \\
\text { - Cruise Lines } \\
\text { - Airline } \\
\text { - Hotel } \\
\text { - Hospital } \\
\text { - Restaurant } \\
\text { - Travel Agent }\end{array}$ & $\begin{array}{l}2 \\
1 \\
1 \\
1 \\
1 \\
1\end{array}$ & 7 \\
\hline $\begin{array}{l}\text { Leisure } \\
\text { - Golf Club } \\
\text { - Health Club } \\
\text { - Movie Cable Network } \\
\text { - Stage Entertainment Firm }\end{array}$ & $\begin{array}{l}1 \\
1 \\
1 \\
1\end{array}$ & 4 \\
\hline $\begin{array}{c}\text { Media \& Telecommunications } \\
\text { - Media (News Service) } \\
\text { - Telecommunication }\end{array}$ & $\begin{array}{l}3 \\
1\end{array}$ & 4 \\
\hline $\begin{array}{l}\text { Finance/Banking } \\
\text { - Retail Banks } \\
\text { - Finance Company } \\
\text { - Private Bank }\end{array}$ & $\begin{array}{l}2 \\
1 \\
1\end{array}$ & 4 \\
\hline $\begin{array}{l}\text { Education } \\
\qquad \quad \text { Higher Education Colleges }\end{array}$ & 2 & 2 \\
\hline Total Sample & & 36 \\
\hline
\end{tabular}

Ng, Irene C. L., Wirtz, Jochen, and Lee, Khai Sheang, (1999) “The Strategic Role Of Unused Service Capacity,” International Journal of Service Industry Management, Vol. 10, No. 2, pp211-238 
TABLE 2

CAPACITY UTILIZATION STRATEGIES EMPLOYED BY THE SAMPLE FIRMS

(MULTIPLE RESPONSES)

\begin{tabular}{|c|c|c|c|}
\hline Capacity Utilization Strategies & $\begin{array}{c}\text { No. of } \\
\text { Companies }\end{array}$ & $\begin{array}{c}\% \text { of } \\
\text { Subtotal }\end{array}$ & $\%$ of Total \\
\hline $\begin{array}{l}\text { Customer Development } \\
\text { Companies that use capacity: } \\
\text { - To build loyalty } \\
\text { - To provide trials }\end{array}$ & $\begin{array}{l}26 \\
16\end{array}$ & $\begin{array}{l}81 \% \\
50 \%\end{array}$ & \\
\hline Subtotal & 32 & $100 \%$ & $89 \%$ \\
\hline $\begin{array}{l}\text { Bundling } \\
\text { Companies that bundle: } \\
\text { - To provide better service value } \\
\text { - To increase demand } \\
\text { - To reduce selling risk (insurance) } \\
\text { - To reduce marketing costs } \\
\text { - To obscure discounts }\end{array}$ & $\begin{array}{l}27 \\
18 \\
14 \\
11 \\
10\end{array}$ & $\begin{array}{l}90 \% \\
60 \% \\
47 \% \\
37 \% \\
33 \% \\
\end{array}$ & \\
\hline Subtotal & 30 & $100 \%$ & $83 \%$ \\
\hline $\begin{array}{l}\text { Employee Endowment } \\
\text { Companies that use capacity for } \\
\text { employee endowment }\end{array}$ & 23 & N.A & $64 \%$ \\
\hline $\begin{array}{l}\text { Exchanging } \\
\text { Companies that exchange: } \\
\text { - To reduce cost } \\
\text { - To extend product range } \\
\text { - To improve yield } \\
\end{array}$ & $\begin{array}{r}15 \\
10 \\
5 \\
\end{array}$ & $\begin{array}{l}79 \% \\
53 \% \\
26 \% \\
\end{array}$ & \\
\hline Subtotal & 19 & $100 \%$ & $53 \%$ \\
\hline $\begin{array}{l}\text { Pledging } \\
\text { Companies that use capacity for } \\
\text { pledging }\end{array}$ & 14 & N.A & $39 \%$ \\
\hline $\begin{array}{l}\text { Entry Deterrence } \\
\text { Companies that use capacity for } \\
\text { deterring entry }\end{array}$ & 9 & N.A & $25 \%$ \\
\hline $\begin{array}{l}\text { Differentiation } \\
\text { Companies that use capacity for } \\
\text { differentiation }\end{array}$ & 4 & N.A & $13 \%$ \\
\hline TOTAL SAMPLE & 36 & N.A & $100 \%$ \\
\hline
\end{tabular}



FIGURE 1

CAPACITY UTILIZATION STRATEGIES - OVERVIEW

\begin{tabular}{|c|c|c|c|c|c|c|}
\hline \multicolumn{7}{|c|}{ Unused Service Capacity Can be Used for: } \\
\hline \begin{tabular}{ll}
\multicolumn{1}{c}{ Customer } \\
Development \\
- & $\begin{array}{l}\text { By building } \\
\text { loyalty (P1a) }\end{array}$ \\
- & $\begin{array}{l}\text { By providing } \\
\text { trials (P1b) }\end{array}$ \\
- & $\begin{array}{l}\text { To develop new } \\
\text { channels (P1c) }\end{array}$
\end{tabular} & \begin{tabular}{ll} 
& \multicolumn{1}{c}{ Bundling } \\
& \\
- & To provide better \\
service value \\
(P2a) \\
- \\
To increase \\
demand (P2b) \\
- $\quad$ To reduce selling \\
risk (P2c) \\
- To reduce \\
marketing costs \\
(P2d) \\
- To obscure \\
discounts $(\mathrm{P} 2 \mathrm{e})$
\end{tabular} & $\begin{array}{ll}\frac{\text { Employee }}{\text { endowment }} \\
\text { - To increase } \\
\text { staff } \\
\text { motivation } \\
\text { and loyalty } \\
\text { (P3) }\end{array}$ & $\begin{array}{ll}\text { Exchanging } \\
\\
\text { - } \\
\text { To reduce cost } \\
\text { (P4a) } \\
\text { - To extend } \\
\text { product range } \\
\text { (P4b) } \\
\text { - To improve yield } \\
\text { (P4c) }\end{array}$ & $\begin{array}{l}\text { Pledging } \\
\\
\text { - To develop } \\
\text { New } \\
\text { Markets } \\
\text { (P5) }\end{array}$ & 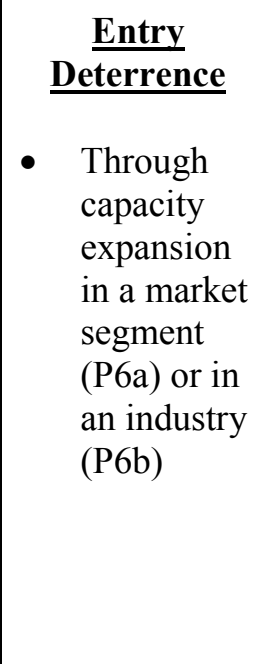 & $\begin{array}{l}\text { Differentiation } \\
\text { - To enhance } \\
\text { service quality } \\
\text { (P7) }\end{array}$ \\
\hline
\end{tabular}

Note: Proposition numbers developed in the paper are provided in parentheses 
FIGURE 2

CAPACITY STRATEGY MODEL

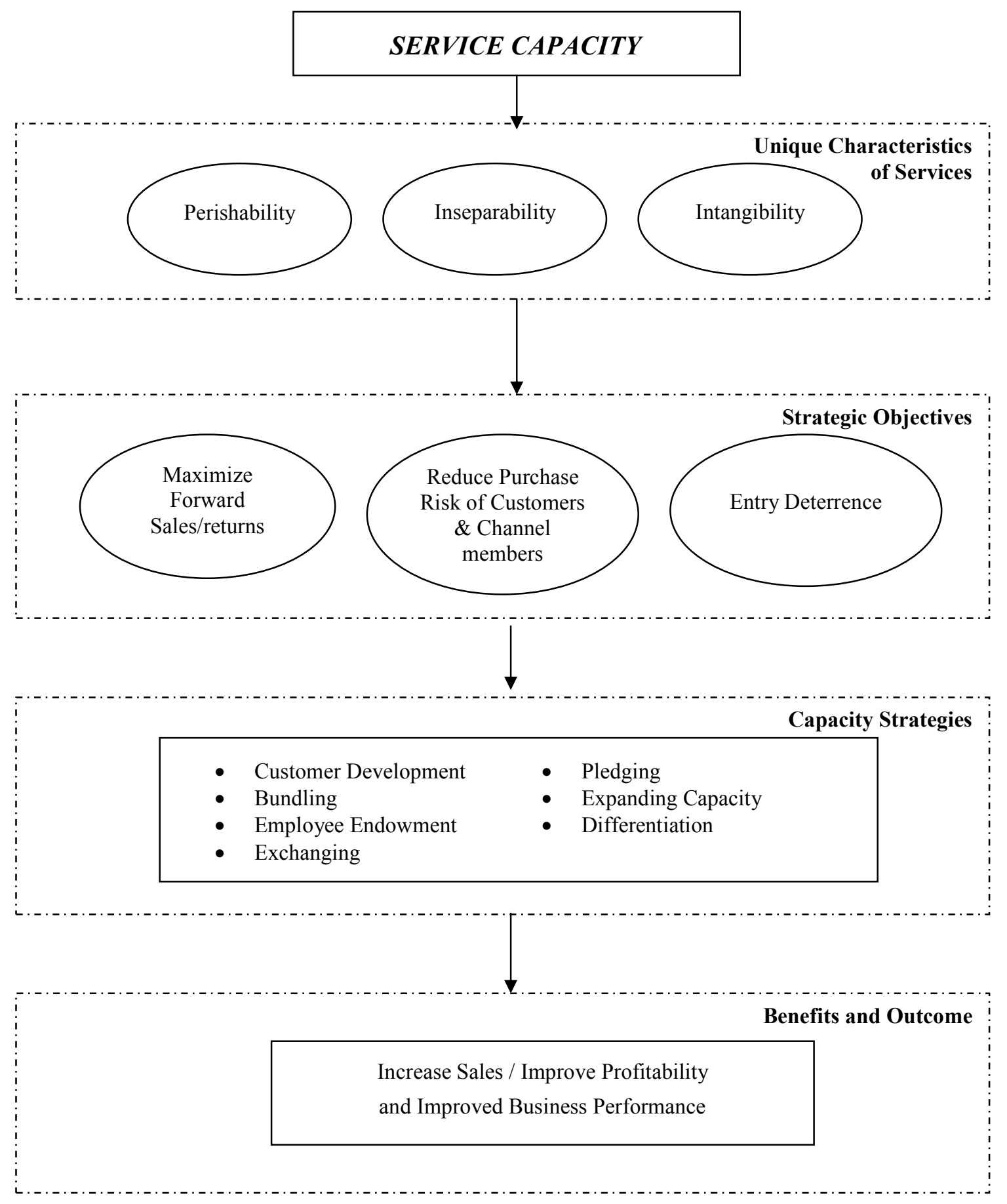




\section{REFERENCES}

Alonzo, Vincent (1996), "The Trouble with Money", Incentive, February, pp. 26-30

Allen, Michael (1988), "Strategic Management of Consumer Services", Long Range Planning, Vol. 21, No. 6, pp. 20-25

Anderson, Erin and Weitz, Barton (1992), "The Use of Pledges to Build and Sustain Commitment in Distribution Channels", Journal of Marketing Research, Vol. 29 (Feb), pp. 1834

Adams, William and Yellen (1976), "Commodity Bundling and the Burden of Monopoly", Quarterly Journal of Economics, Vol. 90 (Aug), pp. 475-498

Badinelli, Ralph D. and Olsen, Michael D. (1990), "Hotel Yield Management Using Optimal Decision Rules", Journal of the International Academy of Hospitality Research, Electronic Journal, URL - http://borg.lib.vt.edu/ejournals/JIAHR/90-11-26.jiahr.html, Iss. 1, (Nov),

Bassett, Glenn (1992), Operations Management for Service Industries, Quorom Books, Westport, Conn.

Bateson, John E.G., (1977), "Do We Need Service Marketing?", Marketing Consumer Services : New Insights, Marketing Science Institute, Report pp. 77-115 
Berry, Leonard L. (1987), "Big Ideas in Services Marketing", Journal of Services Marketing, Vol. 1, No. 1, pp. 5-9

and Parasuraman, A. (1991), Marketing Services : Competing through Quality, Free Press, New York, NY

Bitner, Mary Jo, Booms, Bernard H. and Tetreault, Mary Stanfield (1990), "The Service Encounter: Diagnosing Favorable and Unfavorable Incidents", Journal of Marketing, Vol. 54 (Jan), pp. 71-84

Bradley, Peter (1995), "Alliances could change world shipping patterns", Purchasing, Vol. 119, No. 5, Oct, pp. 47-48

Brausch, John M. and Taylor, Thomas C. (1997), "Who is Accounting for the Cost of Capacity", Management Accounting, Feb, pp. 44-50

Dahlstrom, Robert, Dwyer, F. Robert and Chandrashekaran, Murali (1995), "Environment, Structure and Performance in Interfirm Exchange", Journal of Business-to-Business Marketing, Vol. 2, No. 2, pp. 37-58

Dearden, John (1978), "Cost Accounting Comes to Service Industries," Harvard Business Review, Vol. 56 (Sep-Oct), pp. 132-140 
Dilworth, James B. (1992), Operations Management: Design, Planning and Control for Manufacturing and Services, McGraw-Hill Inc., New York.

Donald, Weinrach J., Mann, Karl, Robinson, Patricia A., and Pharr, Julia (1991), "Dealing with Limited Resources: A Marketing Challenge for Small Business", Journal of Small Business Management, Vol. 29, No. 4.

Dwyer, F. Robert and Sejo, Oh (1987), "Output Sector Munificence Effects on the Internal Political Economy of Marketing Channels", Journal of Marketing Research, Vol. 24, (Nov), pp. $347-368$

Eppen, Gary D., Ward, A. Hanson and Martin (1991), "Bundling - New Products, New Markets, Low Risk", Sloan Management Review, Summer, pp. 7-14

Gronroos, Christian (1991), Service Management and Marketing, Lexington Books, Lexington, Mass.

Gruca, Thomas S. and Sudharshan, D. (1995), "A Framework for Entry Deterrence Strategy: The Competitive Environment, Choices and Consequences", Journal of Marketing, Vol. 59, (Jul), pp. $44-55$ 
Guiltinan, Joseph P. (1987), "The Price Bundling of Services: A Normative Framework", Journal Of Marketing, Vol. 51 (April), pp. 74-85

Gummesson, Evert (1979), "The Marketing of Professional Services: An Organizational

Dilemma", European Journal of Marketing, Vol. 13, No. 5 pp305-318

Gummeson, Evert (1991), "Marketing-orientation Revisited: The Crucuial Role fo the Part-Time Marketer" European Journal of Marketing, Vol. 25, No. 2, pp60-75

Harris, Frederick H. DeB. And Peacock, Peter (1995), "Hold My Place, Please", Marketing Management, Vol. 4, No. 2 (Fall), pp. 34-46

Heskett, James L. (1986), Managing in the Service Economy, Harvard Business School Press

Hope, Christine and Muhlemann, Alan (1997), Service Operations Management, Prentice Hall, Europe.

Langeard, Eric, Bateson, John E.G., Lovelock, Christopher H., Eiglier, Pierre (1981), Services Marketing: New Insights from Customers and Managers, Cambridge, MA: Marketing Science Institute 
Lee, Khai.S., Wee, Chow H. and Chia, Kwok P. (1997), "Dealing with Resource Disadvantage: Generic Strategies for SMEs" Working Paper, Faculty of Business Administration, National University of Singapore.

Lee, M. (1989), "Contingency Approach to Strategies for Service Firms", Journal of Business Research, Vol. 19, No. 4 December, pp. 293-301

Light, Donald (1986), "A Guide for New Distribution Channel Strategies for Service Firms", Journal of Business Strategy, Vol. 7, No. 1, Summer

Lovelock, Christopher (1983), "Classifying Services to Gain Strategic Marketing Insights", Journal of Marketing, Vol. 47 (Summer), pp. 9-20

(1988), "Strategies for Managing Capacity Constrained Service Organizations", in Lovelock, C.H (Ed.) Managing Services: Marketing, Operations, and Human Resources, Prentice-Hall, Englewood Cliffs, NJ, pp. 163-75

(1992), "Seeking Synergy in Service Operations: Seven Things Marketers Need to Know about Service Operations", European Management Journal, Vol. 10, No. 1 (March), pp. $22-29$

Lundberg, L. (1992), "Open New Channels with Barter", Sales and Marketing Strategies and News, March, pp. $9 \& 13$ 
Mabert, V. (1986), "Staffing and Equipment Decisions for Services: An Experimental Analysis", Journal of Operations Management, Vol. 6, Nos. 3/4 (May/Aug), pp. 273-81

Maturi, R. (1989), "Cash, Credit... or a Swap?", Industry Week, Vol. 238, Mar 20, pp. 58-9

McNair, C.J, (1994), "The Hidden Costs of Capacity", Cost Management, Spring, pp. 12-24

Morrall, K. (1986), "Agencies Supply Specialized Workers for Short-term Jobs", Savings Institutions, Vol. 107, No. 9 (September), pp. 34-8

Normann, Richard (1984), Service Management: Strategy \& Leadership in Service Business, John Wiley \& Sons Ltd, Chichester, New York.

Ohmae, Kenichi (1982), The Mind of The Strategist: The Art of Japanese Business, McGrawHill, Inc., New York.

Orsini, J. and Karabozoglu, N. (1988), "Marketing/Production Interfaces in Service Industries", Advance Management Journal, Vol. 53, No. 3, pp. 34-8

Porter, Michael (1985), Competitive Advantage: Creating and Sustaining Superior Performance, The Free Press, New York. 
Prahalad, C.K. and Gary Hamel (1990), "The Core Competence of the Corporation”, Harvard Business Review, Vol. 68, No. 3, pp. 79-91

Reddy, Allan C., Buskirk, Bruce D. and Kaicker, Ajit (1993), "Tangibilizing the Intangibles : Some Strategies for Services Marketing", Journal of Services Marketing, Vol. 7, No. 3, pp. 1317

Sasser, W. Earl (1976), "Match Supply and Demand in Service Industries", Harvard Business Review, Vol. 54 (Nov-Dec), pp. 133-40

Schlesinger, Leonard A., Heskett, James L. (1991), "The Service-Driven Service Company", Harvard Business Review, Sep-Oct, pp. 71-81

Schmalensee, Richard (1984), "Gaussian Demand and Commodity Bundling", Journal of Business, Vol. 57, No. 1, Part 2, pp. 211-230

Schmenner, Roger (1986), "How can Service Business Survive and Prosper?", Sloan Management Review, Vol. 27, No. 3 (Spring), pp. 21-32

Shemwell, Donald J. Jr and Cronin, Joseph J. Jr (1994), "Service Marketing Strategies for Coping with Demand/Supply Imbalances", Journal of Services Marketing, Vol. 8, No. 4, pp. 1424 
Simon, Julian L. (1994), "The Airline Oversales Auction Plan Savings in a Bundle Price: An Examination of a Bundle's Transaction Value", Journal of Marketing Research, Vol. 30 (Aug), pp. $350-358$

Smiley, Robert (1988), "Empirical Evidence on Strategic Entry Deterrence", International Journal of Industrial Organisation, Vol. 6, pp. 181-197

Stone, Merlin (1990), "Marketing Strategies for Leisure Services", Long Range Planning, Vol. 23, No. 5, pp. $76-90$

Taylor, Shirley (1994), "Waiting for Service: The Relationship Between Delays and Evaluations of Service", Journal of Marketing, Vol. 58 (April), pp. 56-69

Thomas, Dan R.E., (1978) "Strategy is Different in Service Business", Harvard Business Review, Vol. 56 (Jul-Aug), pp. 158-165.

Vaccaro, Joseph P. And Kassaye W. Wossen (1997), "Taking advantage of barter in radio", Journal of Services Marketing, Vol. 11, No. 2, pp. 118-127

Venkatesh, R. and Mahajan, Vijay (1993), “A Probabilistic approach to Pricing a Bundle of Products or Services", Journal of Marketing Research, Vol. 30 (Nov), pp. 494-508 
Wenders, John T. (1971), "Excess Capacity as a Barrier to Entry: An Empirical Appraisal”, Journal of Industrial Economics, Vol. 20 (Nov), pp. 14-19

Wilson, Ian (1988), “Competitive Strategies for Service Businesses”, Long Range Planning, Vol. 21, No. 6, pp. 10-12

Wirtz, Jochen, Lee, Meng Chung and Mattila, Anna (1998, forthcoming), “Services in Asia Macro Trends," Asia Pacific Advances in Consumer Research, K.B. Monroe and K. Hung, eds., Provo, UT, USA: Association for Consumer Research, Vol. 3

Yadav, Manjit S. and Monroe, Kent B. (1993), "How Buyers Perceive Savings in a Bundle Price: An Examination of a Bundle's Transaction Value", Journal of Marketing Research, Vol. 30 (Aug), pp. 350-358

Yip, George (1982), “Gateways to Entry”, Harvard Business Review, Vol. 60 (Sep/Oct), pp. 8591

Zaltmann, Gerald, LeMasters, Karen and Heffring, Michael (1982), “Constructing Theories-inuse", Theory Construction in Marketing: Some Thoughts on Thinking, John Wiley \& Sons, Inc.

Zeithaml Valarie A., Parasuraman A. And Berry L. (1985), "Problems and Strategies in Services Marketing”, Journal of Marketing, Vol. 49, No. 2 (Spring), pp. 33-46 